\title{
Effects of coat color pattern and sex on physiological traits and heat tolerance of indigenous goats exposed to solar radiation
}

\author{
Simon Patrick Baenyi (iD. Ahadi Bwihangane Birindwa (iD. Valence Bwana Mutwedu ID. Yannick Mugumaarhahama iD \\ - Arthur Munga - Bienfait Mitima ID. Vanessa Wandja Kamgang iD. Rodrigue Basengere Balthazar Ayagirwe iD
}

SP Baenyi (Corresponding author) - AB Birindwa - VB

Mutwedu - Y Mugumaarhahama - A Munga

Department of Animal Production, Faculty of Agriculture and Environmental Studies, Université Evangélique en Afrique (UEA), Bukavu, Democratic Republic of the Congo.

email: baenyipatrick@gmail.com

\section{B Mitima}

Bio-Medical Laboratory, Université Evangélique en Afrique (UEA), Bukavu, Democratic Republic of the Congo.

\author{
VW Kamgang \\ Mammal Research Institute, Department of Zoology and \\ Entomology, University of Pretoria, Hatfield 0028, South \\ Africa.
}

\section{RBB Ayagirwe}

Department of Animal Production, Faculty of Agriculture and Environmental Studies, Université Evangélique en Afrique (UEA), Bukavu, Democratic Republic of the Congo.

Department of Environment and Rural Development, Institut Superieur de développement rural, Democratic Republic of Congo.

Received: January 15, 2020 - Accepted: February 08, 2020 - Published Online: April 07, 2020

\begin{abstract}
In this century, climate change is one of the major problems affecting livestock productivity. This study aimed at evaluating the effect of body coat color pattern and sex on heat regulation and heat stress tolerance in indigenous goat breeds exposed to solar radiation. In the experiment, 4 bucks and 4 does ( 8 to 9 months age) with black, white, grey and brown coat color were selected and exposed to solar radiation during 12 days during the summer period. Water and feed were served add libitum. The consumption were measured daily at 17:00 for each animal. Rectal temperature (RT) and rate pulse (PR) were measured three-time (7:00, 12:00, and 17:00) every day on each animal during the experimental period. At the end of the experiment, blood samples were collected from the jugular vein and immediately delivered to the lab to determine biochemical (serum protein: albumin and globulin), and hematological parameters. Exposing goats to temperature variation affected the physiological, hematological as well as biochemical parameters in all subjects. The female with a black body coat color was mostly affected. The heat stress induced an increase of RT and PR, an increase in water consumption while depression in food intake was observed. Blood platelets, hematocrits, red cell distribution, white blood cell and albumin were damaged in goats with black coat color compared to goats with white coat color. These variations in physiological, hematological and biochemical parameters in female black goat could affect its productive and reproductive performances in high-temperature environments.
\end{abstract}

Keywords: ambient temperature, heat stress, local goat, physiological reaction, South Kivu

\section{Introduction}

Livestock is one of the important sectors in the world that contributes to about $40 \%$ of agriculture GDP and provide livelihoods and incomes for at least 1.3 billion people worldwide (Salmon 2018). However, climatic variations and global warming threats are becoming major to affect the sustainability of livestock production systems (Gaughan et al 2009). Stress is considered as the reaction of the body to stimuli that disturb homeostasis often with detrimental effects (Chovatiya et al 2014). It induces many unfavorable damages, ranging from discomfort to death of the animal (Etim et al 2013). Solar radiation, high ambient temperature, and humidity are the most important environmental stressing factors reported in animals (Silanikove et al 2000). Nowadays, there is clear evidence that heat stress is one of the most important stressors affecting domestic animals especially in the hots regions of the world (Renaudeau et al 2012). Heat stress can markedly affect animal welfare, the productive and productivity performances of animals in tropical and subtropical regions (Gupta et al 2016). Temperature determines heart rates, metabolic rates, and others important factors in animals. The effect of high temperature is further aggravated when heat stress is accompanied by high ambient humidity (Mayengbam et al 2016). 
Due to their multiple uses (milk production, adaptability in marginal areas and heat tolerance), goats are appreciated by farmers worldwide. Goat is not exigent and can be kept by either women or children. It seems to be the only livestock that fits well for effective utilization in the diverse socio-economic situations of the developing countries. In adverse climatic conditions, they perform well due to their low body mass and small body size, low metabolic requirements, their efficiency of utilization of high fiber forage, their ability to reduce metabolism, and efficiency in water use (Silanikove 1997, 2000). However, the thermal environment is a major factor that negatively affects goat performance (Alam et al 2011). Increased respiration rate and body temperature are the most important signs for heat stress in goat (Alam et al 2011). Excessive heat stress may cause hyperthermia and potentially have several physiological adverse effects on the reproductive functions (Roth et al 2002). It can also reduce meat quality, increase oxidative stress (thereby damaging) as well as enzymatic dysfunction (Davis et al 2001). In the livestock sector, economical losses resulting from the increased rate of animal mortality and the decreased rate of animal performance (Hahn and Mader 1997).

In Ruzizi valley in particular and South- Kivu in general (Democratic Republic of the Congo), the goat is among the most domesticated animals raised in a traditional management contributing to farmers' household incomes (Wasso et al 2018). At the same time, Ruzizi valley is the region in South Kivu that is characterized by high ambient temperature variation $\left(18\right.$ and $\left.29^{\circ} \mathrm{C}\right)$ with a humid and semiarid climate, and a low rainfall less than $500 \mathrm{~mm}$ per year. However, there is no information on the thermoregulation responses of goat in this part of Congo. The purposes of this study was to determine the physiological and the biochemical parameters for heat regulation and heat stress tolerance in indigenous goat in Ruzizi valley in South Kivu province.

\section{Materials and Methods}

Study area

This study was conducted in Ruzizi valley (2'42'24', latitude South and $29^{\circ} 22^{\prime}$ longitude Est.) located in South Kivu in the Eastern part of the Democratic Republic of Congo. It is located between. The Ruzizi valley covers 175000 ha from which 80000 ha are located in DRC where 35000 ha are used for Agriculture, 30000 for pastures and 15000 are occupied by wetlands. The altitude varies between $773 \mathrm{~m}$ and $1000 \mathrm{~m}$. Sandy-clay and clay-sandy are two types of soil characterizing the area. Ruzizi valley has a tropical climate classified as AW according to the classification of Koppen and Geiger in 2018. The average ambient annual temperature varies between 19 and $29^{\circ} \mathrm{C}$ and the average annual rainfall less than $550 \mathrm{~mm}$. The average annual insolation in the Ruzizi valley is of the order of $50 \%$ of the possible astronomical insolation. The maximum insolation period ( $>50 \%)$ coincides with the dry season (May to October) followed by the minimal insolation (41\%) in November and December (www.reliefweb.int).

\section{Ethical approval}

The study protocol was approved by the Ethical Committee of the Université Evangélique en Afrique (UEA).

\section{Animals and experimental design}

Eight indigenous adult goats including four males and four females were selected for the experiment. The selected goats were aged $8-9$ months and were not yet used for reproduction. Bucks and does had almost the same weight (26 to $28 \mathrm{~kg}$ ). Four experimental groups each with two local goats (male and female) were constituted based on four body coat color types including black, grey, white and brown due to their effect on heat effects in livestock adaptability (Peters et al 1982).

The experimental animals were exposed to solar radiant for 9 hours each day (from 7:00 to 17:00) for 12 consecutive days during the dry season which correspond to the pick of heat observed. All the experimental goats were procured locally and were housed together at the same place for a period of one month in the same conditions (feeding, disease control, housing) for their psychological and physiological acclimatization.

During the day, animals were tied outside in direct contact with solar radiant and during the night they were returned in the house. The animals were clinically healthy and were fed each with $3 \mathrm{~kg}$ of Digitaria spp (50\%) and Tripsacum spp $(50 \%)$ which were selected based on their palatability by the goats and their availability in the study area. The total amount of food consumed was considered as the difference between the weight of the initial quantity distributed to animals and the weight of the quantity not consumed (refusal) each day at the same time (17:00). The quality, quantity, time of forage distribution and refusal measurement were respected for all animals in the different batches. Drinking water was available ad libitum, and each animal received the same quantity daily. At the end of each day, the amount (in liters) of water consumed per animals was determined by measuring the residual of the initial amount.

Physiological parameters (rectal temperature; pulse rate) and ambient temperature were also daily measured three times (7:00, 12:00 and 17:00) using the digital thermometer (TruVcare) introduced at 4 to $5 \mathrm{~cm}$ into the animal's rectum; while pulse rate was recorded by observing the flank movement of goat and later confirmed by the auscultation method using the stethoscope in recording the number of heart beats per minute (Schleger and Turner 1965). 
Ambient temperature variation during the experiment

During the study period, the ambient temperature varied proportionally with the time during the day (Figure 1). Average temperature was low in the morning at 7:00 (in between $21^{\circ} \mathrm{C}$ ), high in the midday at 12:00 (in between 33.3 ${ }^{\circ} \mathrm{C}$ ) and in between $27^{\circ} \mathrm{C}$ during the evening.

\section{Hematological and biochemical analysis}

On the last day of the experiment, $5 \mathrm{ml}$ of blood was quickly collected from jugular vein of immobilized animals using the vacutainer syringes with the help of veterinarian. Half of the blood sample was transferred into a test tube with K3 EDTA anticoagulant for hematological parameters, while the rest was centrifuged at $3000 \mathrm{rpm}$ for $15 \mathrm{~min}$ and serum was separated then frozen at $-20^{\circ} \mathrm{C}$ for the evaluation of serum content in albumin and globulin according to methods developed respectively by Kaplan and Glucose (1984); Burtis and Ashwoo (1999). Samples collected into the EDTA tubes were used to determine hematological parameters such as: white blood cell (WBC), red blood cell (RBC), hemoglobin (HGB), hematocrit (HCT), mean corpuscular volume (MCV), mean corpuscular hemoglobin $(\mathrm{MCH})$, red cell distribution (RDW), blood platelets (PLT), mean platelet volume (MPV), and platelets distribution width (PDW) were analyzed immediately after blood collection using an automated MINDRAY BC 3000 machine. All these analyses were carried out in the hematological laboratory at the "Université Evangélique en Afrique".

\section{Data analysis}

Results are expressed as mean $\pm \mathrm{SD}$, and treatment effects among experimental groups and controls were assessed using one-way ANOVA. The differences in mean values were compared using the Tukey HSD test at $P<0.05$. Data analysis was performed using $\mathrm{R}$ Console software.

\section{Results}

Mean rectal temperature variation during the experimental period

Mean rectal temperature (RT) variation during the experimental days is shown in Figure 2. The variation of the RT during the 12 days of the experiment followed the same curve fluctuation with a high average recorded at the tenth day.

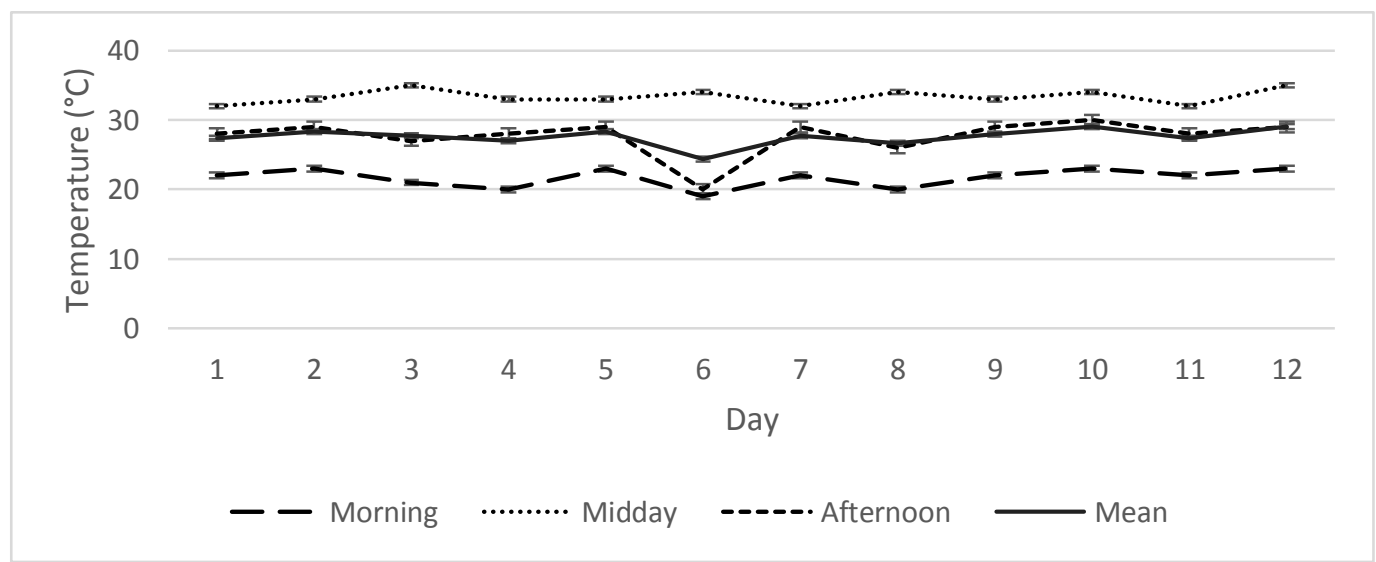

Figure 1 Ambient temperature variation during the experimental period for all animals.

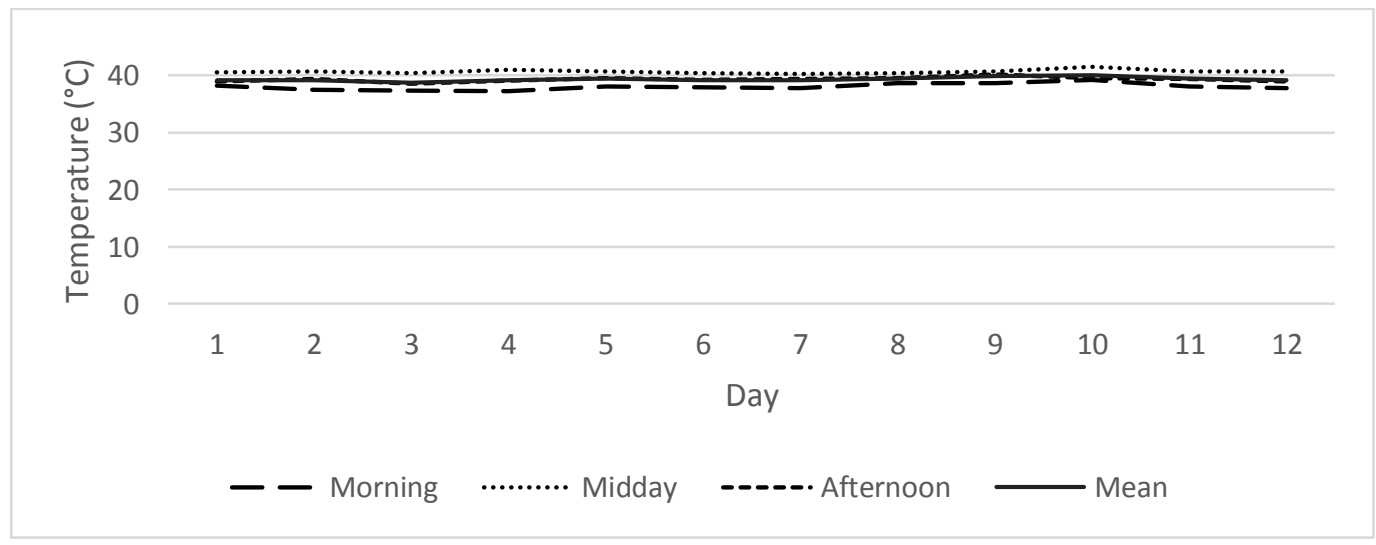

Figure 2 Rectal temperature variation during the experimental period in goats. 
Rectal temperature variation according to sex and coat color

The effects of heat stress on rectal temperature are presented in table 1. Overall RT varied according to the time in the day as well as the animal coat color and sex. Significantly $(P$-value $=0.0000)$ high $\mathrm{RT}$ were recorded during the mid-day time at $12: 00(40.69 \pm 0.54)$ in black ( $40.95 \pm 0.50)$ female goat $(40.98 \pm 0.51)$ compared to the lesser temperatures recorded during the morning at 7:00 (38.06 \pm 0.74$)$. However, this increase was marked in female goats than in male goat $(P=0.0001,0.000$ and 0.0003 at 7:00, $12: 00$ and 17:00, respectively).

\section{Heat stress and on pulse rate variation}

As observed for the RT, the pulse rate (PR) also varied in all individuals throughout the study period increasing in the mid-day before declining slightly later in the day (Figure 2) $(110.46 \pm 8.05)$ in black $(111.33 \pm 6.74)$ female goat (116.33 \pm 8.94$)$. The lowest values were mostly recorded in white and brown male goats either for the RT or the PR.

Table 1 Rectal temperature $\left({ }^{\circ} \mathrm{C}\right)$ variation $($ mean $\pm \mathrm{SD})$.

\begin{tabular}{|c|c|c|c|c|}
\hline Coat color & Sex & 7:00 & $12: 00$ & $17: 00$ \\
\hline \multirow[t]{3}{*}{ Grey } & $\mathrm{F}$ & $38.33 \pm 0.65^{\mathrm{ab}}$ & $40.82 \pm 0.48^{\mathrm{ab}}$ & $39.78 \pm 0.59^{\mathrm{ab}}$ \\
\hline & M & $37.98 \pm 0.73^{\mathrm{ab}}$ & $40.58 \pm 0.53^{\mathrm{abc}}$ & $38.97 \pm 0.55^{\mathrm{c}}$ \\
\hline & Mean & $38.15 \pm 0.70^{\mathrm{a}}$ & $40.70 \pm 0.51^{\mathrm{ab}}$ & $39.38 \pm 0.69^{\mathrm{ab}}$ \\
\hline \multirow[t]{3}{*}{ Black } & $\mathrm{F}$ & $38.56 \pm 0.80^{\mathrm{a}}$ & $40.98 \pm 0.51^{\mathrm{a}}$ & $39.86 \pm 0.59^{\mathrm{a}}$ \\
\hline & M & $37.88 \pm 0.37^{b}$ & $40.92 \pm 0.52^{\mathrm{a}}$ & $39.35 \pm 0.79^{\mathrm{bc}}$ \\
\hline & Mean & $38.22 \pm 0.70^{\mathrm{a}}$ & $40.95 \pm 0.50^{\mathrm{a}}$ & $39.60 \pm 0.73^{\mathrm{a}}$ \\
\hline \multirow[t]{3}{*}{ White } & $\mathrm{F}$ & $37.99 \pm 0.79^{\mathrm{ab}}$ & $40.57 \pm 0.46^{\mathrm{abc}}$ & $39.27 \pm 0.67^{\mathrm{c}}$ \\
\hline & M & $37.77 \pm 0.74^{b}$ & $40.36 \pm 0.43^{b c}$ & $38.90 \pm 0.90^{c}$ \\
\hline & Mean & $37.88 \pm 0.76^{\mathrm{a}}$ & $40.46 \pm 0.45^{\mathrm{b}}$ & $39.08 \pm 0.80^{\mathrm{b}}$ \\
\hline \multirow[t]{3}{*}{ Brown } & F & $38.00 \pm 0.88^{\mathrm{ab}}$ & $41.03 \pm 0.49^{\mathrm{a}}$ & $39.26 \pm 0.60^{\mathrm{c}}$ \\
\hline & M & $37.95 \pm 0.76^{\mathrm{ab}}$ & $40.26 \pm 0.44^{\mathrm{c}}$ & $39,27 \pm 0,59^{\mathrm{c}}$ \\
\hline & Mean & $37.98 \pm 0.80^{\mathrm{a}}$ & $40.64 \pm 0.60^{\mathrm{b}}$ & $39,26 \pm 0,58^{b}$ \\
\hline Total mean & & $38,06 \pm 0,74$ & $40.69 \pm 0.54$ & $39.33 \pm 0.72$ \\
\hline \multirow[t]{3}{*}{$P$-Value } & Color & 0.1983 & 0.0179 & 0.0500 \\
\hline & Sex & 0.0001 & 0.0000 & 0.0003 \\
\hline & Color*Sex & 0.0294 & 0.0000 & 0.0683 \\
\hline LSD & & 0.6510 & 0.3252 & 0.4792 \\
\hline CV (\%) & & 0.94 & 0.58 & 1.34 \\
\hline
\end{tabular}

Heat stress on feed and water consumption

No significant differences in feed intake and water consumption $(P<0.05)$ was observed when considering the type of coat color and sex of the animals (Table 3 ). However, feed intake as well as water consumption were respectively low and high in black goats when compared to white and brown goats.

\section{Heat stress and hematological parameters variation}

Change in the hematological (Table 4) and biochemical (Table 5) parameters on heat stress response in goats were observed in this study. The sex did not have an effect on the hematological parameters. However, there was significant statistics difference $(P<0.05)$ observed on platelets (PLT), hematocrit (HCT) and Red Cell Distribution (RDW) variation according to the coat color type. The average of PLT and RDW was higher in black goats (204.32 \pm 1.12 and $14.24 \pm 1.23$, respectively) while lower in white goats $(66.02 \pm 1.03$ and $12.31 \pm 1.38$, respectively). Inverse scenario was recorded for HCT with a higher average $(40.10 \pm 1.08)$ in white goats and the lower $(24.45 \pm 2.16)$ in black goats The interaction between coat color type and sex influenced $(P<0.05)$ the variation in white blood cell (WBC) which was higher in black female (24.20 \pm 1.13$)$ and lower in white male (17.55 \pm 4.74$)$.

Heat stress and biochemical (globulin and albumin) parameters variation

Results in Table 5 revealed a significant difference $(P$ $<0.05)$ in the variation of albumin and globulin in goats according to the coat color type. High average both for albumin and globulin was recorded in white and brown goats while the lower average for the two biochemical parameters were recorded in black goats $(30.78 \pm 0.59)$ and $(0.50 \pm 0.08)$, respectively. 


\section{Discussion}

The amount of radiant heat absorbed by the animal's coat is partly determined by color, length and condition of its hair (Acharya et al 1995). Physiological responses such as rectal temperature and pulse rate were more considered as indicators of physiological adaptability to heat stress (Sanusi et al 2011; Al-Dawood 2017). They were recorded to be high at mid-day compared to the morning and afternoon. This was expected, as the mid-day ambient temperature was very high compare to those of morning and evening. However, the rectal temperature reported in this study remained within the normal reference range $\left(38-41{ }^{\circ} \mathrm{C}\right)$ for tropical goats (Minka and Ayo 2016).

The highest rectal temperature and pulse rate were recorded in black goats followed by grey goat and brown goat. These results are in accordance to the findings of Okourwa (2015). This implies that the highest rectal temperature observed for black goats was due to the absorption of solar radiation by the dark pigmentation (Okourwa 2015) while light coat colors such as white, grey and brown have an impact on the radiant heat loss exerting its effects on body weight and other productive adaptability factors in livestock species
(Peters et al 1982). The rectal temperature is recognized as an important measure of physiological status as well as ideal indicator for assessment of stress in animals (Lefcourt et al 1986). A rise of less than $1^{\circ} \mathrm{C}$ in rectal temperature, as reported in this study, is enough to reduce performance in most livestock species (McDowell 1976). The increase in pulse rate following animal coat characteristics was also reported by Okourwa (2015) in sheep with black coat color (87.49 beats/min) than the sheep with light brown coat color $(79.00$ beats/min). This increase in pulse rate may be due to vasodilatation of skin capillary bed and consequently increase in blood flow to body surface areas to facilitate heat dissipation (Wojtas et al 2014). The high pulse rate observed in goat with black coat color could probably due to highest rectal temperature associated with the black coat which could exceeds the comfort zone, thereby resulting in redistribution of blood to peripheral tissue during heat exposure (Al-Haidary et al 2012). Considering the sex for all goats with different body coat color type, the females were more affected by the heat stress than bucks $(P<0.05)$. These results are similar to the findings of Acharya et al (1995) in goats reared in the hot tropic.

Table 2 Effect of solar radiation on the pulse rate (beats/minute) variation (mean $\pm \mathrm{SD}$ ).

\begin{tabular}{lcccc}
\hline Coat color & Sex & $7: 00$ & $12: 00$ & $17: 00$ \\
\hline Grew & F & $91.00 \pm 10.39^{\mathrm{ab}}$ & $114.33 \pm 6.71^{\mathrm{a}}$ & $101.33 \pm 7.10^{\mathrm{a}}$ \\
& M & $88.33 \pm 6.92^{\mathrm{ab}}$ & $108.33 \pm 5.52^{\mathrm{ab}}$ & $99.33 \pm 6.11^{\mathrm{b}}$ \\
Mean & $89.67 \pm 8.74^{\mathrm{ab}}$ & $111.33 \pm 6.74^{\mathrm{a}}$ & $100.33 \pm 6.56^{\mathrm{a}}$ \\
& F & $94.00 \pm 7.72^{\mathrm{a}}$ & $116.33 \pm 8.94^{\mathrm{a}}$ & $103.00 \pm 9.36^{\mathrm{a}}$ \\
& M & $89.00 \pm 8.88^{\mathrm{ab}}$ & $112.00 \pm 9.03^{\mathrm{ab}}$ & $100.00 \pm 10.09^{\mathrm{a}}$ \\
White & Mean & $91.50 \pm 8.53^{\mathrm{a}}$ & $114.17 \pm 9.06^{\mathrm{a}}$ & $101.50 \pm 9.64^{\mathrm{a}}$ \\
& F & $86.67 \pm 11.61^{\mathrm{ab}}$ & $107.00 \pm 7.06^{\mathrm{ab}}$ & $103.67 \pm 5.52^{\mathrm{a}}$ \\
Brown & M & $83.67 \pm 11.75^{\mathrm{b}}$ & $104.33 \pm 6.92^{\mathrm{b}}$ & $98.67 \pm 5.21^{\mathrm{b}}$ \\
& Mean & $85.17 \pm 11.53^{\mathrm{b}}$ & $105.67 \pm 6.97^{\mathrm{b}}$ & $101.17 \pm 5.84^{\mathrm{a}}$ \\
& F & $87.33 \pm 10.21^{\mathrm{ab}}$ & $111.67 \pm 6.26^{\mathrm{ab}}$ & $98.33 \pm 4.96^{\mathrm{a}}$ \\
Total mean & M & $84.33 \pm 8.94^{\mathrm{ab}}$ & $109.67 \pm 8.26^{\mathrm{ab}}$ & $93.00 \pm 10.67^{\mathrm{a}}$ \\
\hline$P$-value & Mean & $85.83 \pm 9.51^{\mathrm{b}}$ & $110.67 \pm 7.24^{\mathrm{ab}}$ & $95.67 \pm 8.58^{\mathrm{b}}$ \\
\hline & & $88.04 \pm 9.86$ & $110.46 \pm 8.05$ & $99.67 \pm 8.04$ \\
\hline
\end{tabular}

It has been noticed that the interaction between heat stress and nutrition could be marked by the reduction in feed intake which can be associated with the higher water consumption frequency (Valente et al 2015). In addition, heat stressed animals reduce their feed intake and slow down their basal metabolism causing hypo-function of thyroid gland in order to prevent the additional metabolic heat production (McManus et al 2009). These results are different with the 
findings of Acharya et al (1995), McManus et al (2009), Salama et al (2014), Bagath et al (2017), Darcan and Silanikove (2018). However, black goats seem to have a lowest food intake and a highest water consumption. As these animals had the highest rectal temperature and pulse rate, these findings can be explained by the fact where the feed intake is an adaptive response of the animal to reduce metabolic heat because the heat increment of feeding is an important source of heat production. Since heat stress increment from voluntary activity, rumen fermentation, feed digestion, nutrient absorption and metabolism are reduced when feed intake is less, then not as much heat needs to be dissipated by the animals (Lu 1989). However, the productive performances such as growth, milk yield and reproduction are also reduced because the nutrient supply is below requirements for production (Gupta and Mondal 2019).

Several phenotypic and genotypic traits, which can a rise over generations through slow modifications as goats adapt to environmental challenges, can impact with the adaptive potential to goats in harsh environmental conditions. The adaptive process can be expanded to include reproductive, productive, Neuro-endocrine, physiological, behavioral, hematological and biochemical responses which combine to promote survival in a specific environment (Rojas-Downing et al 2017). Several factors such as species, breed, sex, age, nutrition, diseases, physiological stage and seasonal variations can affect the pattern of hematological values (Bhat et al 2011; Al-Eissa et al 2012).

Table 3 Effect of heat stress on feed and water consumption (mean \pm SD).

\begin{tabular}{|c|c|c|c|}
\hline Coat color & Sex & $\begin{array}{l}\text { Feed consumption } \\
\text { (g/animal/12days) }\end{array}$ & $\begin{array}{l}\text { Water consumption } \\
\qquad(\mathrm{ml})\end{array}$ \\
\hline \multirow[t]{3}{*}{ Grey } & $\mathrm{F}$ & $2087.50 \pm 140.01$ & $2437.50 \pm 113.07$ \\
\hline & M & $2095.83 \pm 132.22$ & $2520.83 \pm 167.14$ \\
\hline & Mean & $2091.67 \pm 133.24$ & $2479.17 \pm 145.90$ \\
\hline \multirow[t]{3}{*}{ Black } & $\mathrm{F}$ & $2037.50 \pm 111.04$ & $2604.17 \pm 167.14$ \\
\hline & M & $2050.00 \pm 156.67$ & $2562.50 \pm 155.40$ \\
\hline & Mean & $2043.75 \pm 132.95$ & $2583.33 \pm 159.26$ \\
\hline \multirow[t]{3}{*}{ White } & $\mathrm{F}$ & $2087.50 \pm 156.85$ & $2541.67 \pm 208.71$ \\
\hline & M & $2112.50 \pm 122.71$ & $2520.83 \pm 167.14$ \\
\hline & Mean & $2100.00 \pm 138.31$ & $2531.25 \pm 185.22$ \\
\hline \multirow[t]{3}{*}{ Brown } & $\mathrm{F}$ & $2079.17 \pm 143.75$ & $2583.33 \pm 162.83$ \\
\hline & M & $2108.33 \pm 97.31$ & $2583.33 \pm 162.83$ \\
\hline & Mean & $2093.75 \pm 120.97$ & $2583.33 \pm 159.26$ \\
\hline Total mean & & $2082.29 \pm 131.39$ & $2544.27 \pm 166.21$ \\
\hline \multirow[t]{3}{*}{$P$-value } & Color & 0.2127 & 0.1055 \\
\hline & Sex & 0.4774 & 0.8726 \\
\hline & Color*Sex & 0.9153 & 0.5457 \\
\hline LSD & & 82.996 & 133.38 \\
\hline CV $(\%)$ & & 4.79 & 6.22 \\
\hline
\end{tabular}

An understanding of hematological characteristics is an important tool that can be used as a sensitive index to monitor health status and physiological changes in farm animals. In this study PLT, HCT and RDW were varying according to the coat color type. WBC varied according to the interaction between coat color type and sex. PLTs are source of phospholipid, which is needed for the interaction of coagulation factors to form a fibrin clot (Singh et al 2010). RDW width is a major indicator of heterogeneity in the size of RBCs and PLT, respectively. It is a more specific indicator of PLT activation since it is not elevated during single PLT distention caused by PLT swelling (Vagdatli et al 2010). 
Table 4 Heat stress and hematological parameters variation (mean \pm SD).

\begin{tabular}{|c|c|c|c|c|c|c|c|c|c|c|c|}
\hline $\begin{array}{l}\text { Coat } \\
\text { color }\end{array}$ & Sex & $\operatorname{PLT}(\#)$ & MPV (fL) & HCT (\%) & $\mathrm{MCV}(\mathrm{fl})$ & $\begin{array}{c}\mathrm{MCH} \\
\text { (picogram) }\end{array}$ & RDW (\%) & PDW (\%) & WBC $(\mu \mathrm{l})$ & HGB (\%) & $\operatorname{RBC}\left(10^{6} / \mathrm{ml}\right)$ \\
\hline \multirow[t]{3}{*}{ White } & $\mathrm{F}$ & $66.06 \pm 1.34^{\mathrm{d}}$ & $0.44 \pm 0.62$ & $39.98 \pm 1.23^{\mathrm{a}}$ & $20.17 \pm 0.11$ & $3.20 \pm 1.42$ & $12.58 \pm 1.9^{\mathrm{bc}}$ & $7.80 \pm 1.56$ & $22.85 \pm 0.07^{\mathrm{a}}$ & $7.90 \pm 0.14$ & $1.06 \pm 0.08$ \\
\hline & M & $65.98 \pm 1.17^{\mathrm{d}}$ & $0.11 \pm 0.15$ & $40.21 \pm 1.40^{\mathrm{a}}$ & $11.15 \pm 12.6$ & $3.12 \pm 1.44$ & $12.05 \pm 1.3^{\mathrm{c}}$ & $7.32 \pm 1.16$ & $17.55 \pm 4.74^{\mathrm{b}}$ & $7.70 \pm 3.39$ & $0.81 \pm 0.15$ \\
\hline & Mean & $66.02 \pm 1.03$ & $0.27 \pm 0.42$ & $40.10 \pm 1.08$ & $15.66 \pm 8.98$ & $3.16 \pm 1.17$ & $12.31 \pm 1.38$ & $7.56 \pm 1.15$ & $20.20 \pm 7.07^{\mathrm{a}}$ & $7.65 \pm 1.08$ & $0.93 \pm 0.18$ \\
\hline \multirow[t]{3}{*}{ Grey } & $\mathrm{F}$ & $168.39 \pm 1.71^{\mathrm{b}}$ & $0.52 \pm 0.74$ & $25.39 \pm 1.65^{\mathrm{cd}}$ & $21.50 \pm 1.41$ & $3.50 \pm 1.36$ & $13.17 \pm 1.5^{\mathrm{b}}$ & $8.16 \pm 1.46$ & $23.95 \pm 2.47^{\mathrm{ab}}$ & $9.25 \pm 1.06$ & $3.09 \pm 1.20$ \\
\hline & M & $167.04 \pm 0.23^{b}$ & $0.42 \pm 0.59$ & $26.62 \pm 2.83^{\mathrm{c}}$ & $21.16 \pm 1.33$ & $3.31 \pm 1.27$ & $13.17 \pm 1.4^{\mathrm{b}}$ & $8.16 \pm 1.35$ & $22.45 \pm 0.07^{\mathrm{ab}}$ & $7.85 \pm 0.78$ & $1.44 \pm 0.73$ \\
\hline & Mean & $167.72 \pm 1.27$ & $0.47 \pm 0.55$ & $26.00 \pm 2.02$ & $21.33 \pm 1.14$ & $3.40 \pm 1.08$ & $13.17 \pm 1.17$ & $8.16 \pm 1.15$ & $23.2 \pm 1.25^{\mathrm{a}}$ & $8.55 \pm 1.11$ & $2.26 \pm 1.25$ \\
\hline \multirow[t]{3}{*}{ Black } & $\mathrm{F}$ & $204.68 \pm 1.45^{\mathrm{a}}$ & $0.80 \pm 1.13$ & $24.20 \pm 2.40^{\mathrm{d}}$ & $22.26 \pm 1.53$ & $3.53 \pm 1.85$ & $14.31 \pm 1.5^{\mathrm{a}}$ & $8.40 \pm 0.85$ & $24.20 \pm 1.13^{\mathrm{a}}$ & $9.95 \pm 0.49$ & $3.58 \pm 3.05$ \\
\hline & M & $203.97 \pm 1.07^{\mathrm{a}}$ & $0.61 \pm 0.86$ & $24.70 \pm 2.83^{\mathrm{cd}}$ & $22.25 \pm 1.34$ & $3.31 \pm 1.14$ & $14.17 \pm 1.5^{\mathrm{a}}$ & $8.14 \pm 1.29$ & $22.35 \pm 0.07^{\mathrm{a}}$ & $8.95 \pm 0.64$ & $1.15 \pm 0.19$ \\
\hline & Mean & $204.32 \pm 1.12$ & $0.71 \pm 0.83$ & $24.45 \pm 2.16$ & $22.26 \pm 1.17$ & $3.42 \pm 1.26$ & $14.24 \pm 1.23$ & $8.27 \pm 0.90$ & $23.27 \pm 1.67^{\mathrm{a}}$ & $9.45 \pm 0.74$ & $2.36 \pm 2.26$ \\
\hline \multirow[t]{3}{*}{ Brown } & $\mathrm{F}$ & $156.35 \pm 0.92^{\mathrm{c}}$ & $0.47 \pm 0.66$ & $34.25 \pm 1.76^{\mathrm{b}}$ & $20.67 \pm 1.45$ & $3.49 \pm 1.48$ & $12.66 \pm 1.6^{\mathrm{bc}}$ & $8.14 \pm 1.41$ & $22.33 \pm 2.23^{\mathrm{a}}$ & $8.36 \pm 1.38$ & $1.15 \pm 0.25$ \\
\hline & M & $155.55 \pm 0.64^{\mathrm{c}}$ & $0.30 \pm 0.42$ & $34.50 \pm 1.41^{\mathrm{b}}$ & $20.10 \pm 0.71$ & $3.17 \pm 1.49$ & $12.33 \pm 1.1^{\mathrm{c}}$ & $8.10 \pm 1.41$ & $23.68 \pm 2.72^{\mathrm{a}}$ & $7.95 \pm 0.21$ & $0.86 \pm 0.52$ \\
\hline & Mean & $155.95 \pm 0.79$ & $0.39 \pm 0.47$ & $34.37 \pm 1.31$ & $20.38 \pm 0.99$ & $3.33 \pm 1.23$ & $12.49 \pm 1.07$ & $8.12 \pm 1.15$ & $23.00 \pm 2.18^{\mathrm{a}}$ & $7.80 \pm 1.96$ & $1.00 \pm 0.37$ \\
\hline \multicolumn{2}{|l|}{ Total mean } & $148,50 \pm 52,5$ & $0.46 \pm 0.55$ & $8.03 \pm 1.02$ & $31.23 \pm 6.74$ & $19.91 \pm 4.9$ & $3.33 \pm 1.07$ & $13.05 \pm 1.3$ & $21.42 \pm 3.87$ & $8.36 \pm 1.38$ & $1.64 \pm 1.36$ \\
\hline \multirow[t]{3}{*}{ P-value } & Color & 0.0000 & 0.5000 & 0.0003 & 0.2133 & 0.1281 & 0.0026 & 0.0661 & 0.3209 & 0.4926 & 0.2922 \\
\hline & Sex & 0.0570 & 0.1390 & 0.1392 & 0.3342 & 0.1835 & 0.1182 & 0.5811 & 0.0708 & 0.7088 & 0.7749 \\
\hline & Color*Sex & 0.5217 & 0.8914 & 0.2869 & 0.5044 & 0.9176 & 0.5408 & 0.2449 & 0.0230 & 0.7329 & 0.3219 \\
\hline LSD & & 1.3169 & 0.9270 & 0.6665 & 2.097 & 11.897 & 0.5572 & 0.6657 & 7.6068 & 4.1531 & 3.7198 \\
\hline CV (\%) & & 0.37 & 47.42 & 2.65 & 1.49 & 22.75 & 7.58 & 1.91 & 8.88 & 17.89 & 81.76 \\
\hline
\end{tabular}


Table 5 Effect of heat stress on the variation of globulin and albumin (mean \pm SD).

\begin{tabular}{|c|c|c|c|}
\hline Coat color & Sex & Albumine $(\mathrm{g} / \mathrm{l})$ & Glucose $(\mathrm{g} / \mathrm{l})$ \\
\hline \multirow[t]{3}{*}{ Grey } & $\mathrm{F}$ & $30.60 \pm 0.57^{\mathrm{d}}$ & $0.45 \pm 0.07^{b c}$ \\
\hline & M & $30.95 \pm 0.78^{\mathrm{d}}$ & $0.55 \pm 0.07^{\mathrm{bc}}$ \\
\hline & Mean & $32.18 \pm 0.57^{\mathrm{c}}$ & $0.65 \pm 0.13^{b}$ \\
\hline \multirow[t]{3}{*}{ White } & $\mathrm{F}$ & $33.70 \pm 0.99^{\mathrm{bc}}$ & $0.60 \pm 0.14^{\mathrm{bcd}}$ \\
\hline & M & $35.40 \pm 0.28^{\mathrm{a}}$ & $0.75 \pm 0.07^{\mathrm{ab}}$ \\
\hline & Mean & $34.55 \pm 1.15^{\mathrm{a}}$ & $0.68 \pm 0.13^{b}$ \\
\hline \multirow[t]{3}{*}{ Black } & $\mathrm{F}$ & $32.10 \pm 0.85^{\mathrm{e}}$ & $0.65 \pm 0.07^{\mathrm{d}}$ \\
\hline & M & $32.25 \pm 0.49^{\mathrm{e}}$ & $0.65 \pm 0.21^{\mathrm{cd}}$ \\
\hline & Mean & $30.78 \pm 0.59^{d}$ & $0.50 \pm 0.08^{c}$ \\
\hline \multirow[t]{3}{*}{ Brown } & F & $33.05 \pm 0.35^{\mathrm{cd}}$ & $0.75 \pm 0.07^{\mathrm{ab}}$ \\
\hline & M & $34.60 \pm 0.85^{\mathrm{ab}}$ & $0.85 \pm 0.07^{\mathrm{a}}$ \\
\hline & Mean & $33.83 \pm 1.04^{\mathrm{b}}$ & $0.80 \pm 0.08^{\mathrm{a}}$ \\
\hline Total mean & & $32.83 \pm 1.71$ & $0.66 \pm 0.15$ \\
\hline \multirow[t]{3}{*}{$P$-value } & Color & 0.0004 & 0.0117 \\
\hline & Sex & 0.0268 & 0.2508 \\
\hline & Color*Sex & 0.1437 & 0.1095 \\
\hline LSD & & 1.0992 & 0.1534 \\
\hline CV $(\%)$ & & 1.54 & 8.52 \\
\hline
\end{tabular}

However, in this study, hematological parameters seem to be most damaged in black coat color goats. According to Ribeiro et al (2018), animals alter hematological parameters to maintain a stable body temperature, i.e., to maintain RT and PR within the limits recommended for this species and they adjust these parameters to survive both food and water shortages as well as high temperatures. This seem to be normal as the black coat color goats were most affected with physiological parameters as well as food and water consumption.

Results of the present study have indicated that glucose and albumin was mostly low in goats with black coat color. These results are similar to those found by Okourwa (2015) in black and light brown West African dwarf male sheep in southern Nigeria. Serum biochemical parameters contribute to the viscosity and maintenance of the normal blood pressure and the physiological states of animals. They are also important in the proper maintenance of the osmotic pressure between the circulating fluid and the fluid in the tissue in order to facilitate the exchange of materials between the blood and cells (Ocak et al 2009). The general low values albumin observed in goats with black coat color could be due to heat shock and increase in blood volume to maintain both homoeothermic peripheral vasodilatation and sweating which subsequently caused low in plasma proteins concentration in serum (Helal et al 2010).

\section{Conclusions}

The increase in pulse rate frequency, the decrease in feed intake and the increase in water consumption observed may be considered the main mechanism for control of thermal stressed black goats under the imposed environmental conditions characterized by the high temperature. However, these changes affect negatively hematological and biochemical components that can negatively affect goat production and productivity. Goats with white and brown coat color had shown an impact on the radiant heat loss that could exert its effects on body weight and other productive adaptability factors.

\section{Acknowledgements}

Authors acknowledge the Université Evangélique en Afrique for manifold support to this work which was graciously been funded through the University project on improvement of research and teaching quality funded by Pain pour le Monde (Projet A-COD-2018-0383).

\section{Conflict of Interest}

The authord declare no conflict of interest. 


\section{References}

Acharya R M, Gupta U D, Sehgal JP, Singh M (1995) Coat characteristics of goats in relation to heat tolerance in the hot tropics. Small Ruminant Research 18:245-248.

Alam, MM, Hashem MA, Rahman MM, Hossain MM, Haque MR, Sobhan Z, Islam MS (2011) Effect of heat stress on behavior, physiological and blood parameters of goat. Progressive Agriculture 22:37-45.

Al-Dawood A (2017) Towards heat stress management in small ruminants-a review. Annals of Animal Science 17:59-88.

Al-Eissa MS, Alkahtani S, Al-Farraj SA, Alarifi SA, Al-Dahmash B, Al-Yahya H (2012) Seasonal variation effects on the composition of blood in Nubian ibex (Capra nubiana) in Saudi Arabia. African Journal of Biotechnology 11:1283-1286.

Al-Haidary AA, Aljumaah RS, Alshaikh MA, Abdoun KA, Samara EM, Okab AB, Alfuraiji MM (2012) Thermoregulatory and physiological responses of Najdi Sheep exposed to environmental heat load prevailing in Saudi Arabia. Pakistan Veterinary Journal 32:515-519.

Bhat SA, Mir MUR, Qadri S (2011) Hematological and biochemical parameters of Kashmiri goats in different climatic conditions. International Journal Agro Vet Med Science 5:481-487.

Burtis CA, Ashwood ER (1994) Tietz textbook of clinical chemistry. Amer Assn for Clinical.

Chaidanya K, Soren, NM, Sejian V, BagathM, Manjunathareddy GB, Kurien EK, Varma G, Bhatta R (2017) Impact of heat stress, nutritional stress and combined (heat and nutritional) stresses on rumen associated fermentation characteristics, histopathology and HSP70 gene expression in goats. Journal of Animal Behaviour and Biometeorology 5:36-48.

Chovatiya R, Medzhitov R (2014) Stress, inflammation, and defense of homeostasis. Molecular Cell 54:281-288.

Darcan, NK, Silanikove N (2018) The advantages of goats for future adaptation to Climate Change: A conceptual overview. Small Ruminant Research 163:34-38.

Davis MB, Shaw RG (2001) Range shifts and adaptive responses to Quaternary climate change. Science 292:673-679.

Etim NN, Williams ME, Evans EI, Offiong EEA (2013) Physiological and behavioral responses of farm animals to stress: Implications to animal productivity. American Journal of Advanced Agricultural Research 1:53-61.

Gaughan JB, Ebi KL, Burton I, McGregor GR (2009) Response of domestic animals to climate challenges. In Biometeorology for adaptation to climate variability and change: Springer Berlin: Germany 131-17.

Gupta M, Mondal T (2019) Heat stress and thermoregulatory responses of goats: a review. Biological Rhythm Research 1-27.

Gupta SK, Shinde KP, Lone SA, Thakur A, Kumar N (2016) The potential Impact of heat stress on production and reproduction of dairy animals: Consequences and possible solutions: A Review. International Journal of Science, Environment and Technology 5:903-911.

Hahn GL, Mader TL, (1997) Heat waves in relation to thermoregulation, feeding behavior and mortality of feedlot cattle. In Proceedings, Fifth International Livestock Environment Symposium.

Helal A, Hashem ALS, Abdel-Fattah MS, El-Shaer HM, (2010) Effect of heat stress on coat characteristics and physiological responses of Balady and Damascus goats in Sinai, Egypt. AmericanEurasian Journal of Agricultural and Environmental Science 7:60-69.

Kaplan A, Glucose KA (1984) Clin chem The CV Mosby Co. St Louis. Toronto. Princeton 436.

Lefcourt AM, Bitman J, Wood DL, Stroud B (1986) Radio telemetry system for continuously monitoring temperature in cows. Journal of Dairy Science 69:237-242.

Mayengbam P, Tolenkhomba TC, Upadhyay RC (2016) Expression of heat-shock protein 72 mRNA in relation to heart rate variability of Sahiwal and Karan-Fries in different temperature-humidity indices. Veterinary World 9:1051.

Lu CD, (1989) Effect of heat stress on goat production. Small Ruminant Research 2:151-162.

McDowell RE, Hooven NE, Comoers JK (1976) Effect of climate on performance of Holstein in first lactation. Journal of Dairy Science 59:965-973.

McManus C, Paludo GR, Louvandini H, Gugel R, Sasaki LCB, Paiva SR (2009) Heat tolerance in Brazilian sheep: physiological and blood parameters. Tropical Animal Health and Production 41:95-101.

Minka NS, Ayo JO (2016) Effects of cold-dry (Harmattan) and hotdry seasons on daily rhythms of rectal and body surface temperatures in sheep and goats in a natural tropical environment. Journal Circadian Rhythms 14:1-11.

Ocak S, Darcan N, Cankaya S, Inal TC, (2009) Physiological and biochemical responses in German fawn kids subjected to cooling treatments under Mediterranean climate condition. Turkish Journal of Veterinary and Animal Sciences 33:455-461.

Okoruwa MI (2015) Effect of coat characteristics on physiological traits and heat tolerance of West African Dwarf sheep in Southern Nigeria. Open Journal of Animal Sciences 5:351.

Peters KJ, Horst P, Kleinheisterkamp HH (1982) The importance of coat color and coat type as indicators of productive adaptability of beef cattle in a subtropical environment. Tropical Animal Production 7:296-304.

Renaudeau D, Collin A, Yahav S, De Basilio V, Gourdine JL, Collier RJ (2012) Adaptation to hot climate and strategies to alleviate heat stress in livestock production. Animal 6:707-728.

Ribeiro NL, Costa RG, Pimenta Filho EC, Ribeiro MN, Bozzi R (2018) Effects of the dry and the rainy season on endocrine and physiologic profiles of goats in the Brazilian semi-arid region. Italian Journal Animal Science 17:454-461.

Rojas-Downing MM, Nejadhashemi AP, Harrigan T, Woznicki SA (2017) Climate change and livestock: Impacts, adaptation, and mitigation. Climate Risk Management 16:145-163.

Roth Z, Arav A, Braw-Tal R, Bor A, Wolfenson D (2002) Effect of treatment with follicle-stimulating hormone or bovine somatotropin on the quality of oocytes aspirated in the autumn from previously heat-stressed cows. Journal of Dairy Science 85:398-1405.

Salama AAK, Caja G, Hamzaoui S, Badaoui B, Castro-Costa A, Facanha D E, Bozzi R (2014) Different levels of response to heat stress in dairy goats. Small Ruminant Research 121:73-79.

Salmon G (2018) Fact Check 2: Livestock and Economy.

Sanusi AO, Peters SO, Sonibare AO, Ozojie, MO (2011) Effect of coat color on heat stress among West African Dwarf sheep. Nigerian Journal of Animal Production 38:28-36. 
Schleger AV, Turner HG (1965) Sweating rates of cattle in the field and their reaction to diurnal and seasonal changes. Australian Journal of Agricultural Research 16:92-106.

Shiva PS, Gopal D, Ramachandran N, Yogender K, Nandini S, Ashok K (2018) Endocrine and hematobiochemical profile of lambs raised in a semiarid region with different growth potentials during the postweaning period. Turkish Journal of Veterinary and Animal Sciences 42:120-129

Silanikove N (2000) Effects of heat stress on the welfare of extensively managed domestic ruminants. Livestock Production Science 67:1-18.

Silanikove N (1997) Why goats raised on harsh environment perform better than other domesticated animals. Options Mediterraneennes $34: 185-194$

Singh KB, Taneja SK (2010) Effect of long-term excessive Zn supplementation on blood lipid profile and tissue minerals status in wistar rat. Journal of Experimental Sciences 1:4-9.
Trinder P (1969) Determination of glucose in blood using glucose oxidase with an alternative oxygen acceptor. Annals of clinical Biochemistry 6:24-27.

Vagdatli E, Gounari E, Lazaridou E, Katsibourlia E, Tsikopoulou F, Labrianou I (2010) Platelet distribution width: a simple, practical and specific marker of activation of coagulation. Hippokratia 14:28-32.

Valente ÉEL, Chizzotti ML, Oliveira CVR, Galvão MC, Domingues SS, Castro Rodrigues A, Ladeira MM (2015) Intake, physiological parameters and behavior of Angus and Nellore bulls subjected to heat stress. Semina: Ciências Agrárias 36:4565-4574.

Wasso DS, Akilimali JI, Patrick B, Bajope JB (2018) Élevage caprin: Situation actuelle, défis et impact socio-économique sur la population du territoire de Walungu, République Démocratique du Congo. Journal of Applied Biosciences 129:13050-13060.

Wojtas K, Cwynar P, Kolacz R (2014) Effect of thermal stress on physiological and blood parameters in merino sheep. Bulletin of the Veterinary Institute in Pulawy 58: 283-288. 